\title{
Borders and Transportation, Autonomy and Linguistic Minorities in the Julian Alps and Eastern Pyrenees. A Comparative Case Study in Political Geography
}

\author{
Maria Paola Pagnini, Rome, and André Louis SANGUIN, Paris*
}

\section{Content}

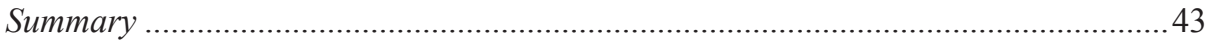

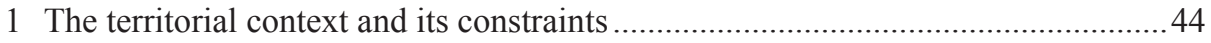

2 Border communities: A story of wrangling and tossing ............................................ 45

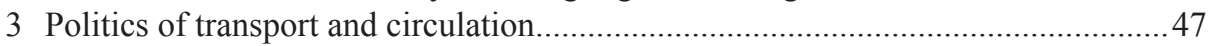

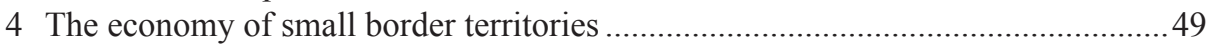

5 Cross-border cooperation in the heart of mountain ranges ..................................50

6 Linguistic and cultural autonomy of small mountain territories ...............................52

7 Conclusion: A game of similarities and differences .............................................54



\section{Summary}

Although separated by $1,100 \mathrm{~km}$, the three small Alps-Adriatic territories (Valcanale, Slavia Friulana, Goriziano) and the three small Eastern Pyrenees 'territories (Val d'Aran, Andorra, Cerdanya) have many features in common. For all, mountain environmental constraints, partitioning by valleys, linguistic isolation and transport difficulties have generated micro-societies with pronounced individuality. In order to overcome these handicaps, these voluntaristic communities implemented trunk roads to facilitate economic development and create better connections with the state to which

* Maria Paola Pagnini, Prof. PhD., Dean, Faculty of Political Science and International Relations, Niccolo Cusano University, Via Casalmonferrato 2/B, I-00182 Roma, Italy; e-mail: mp.pagnini@virgilio.it; André Louis SANGuIN, Prof. PhD., Faculty of Geography, University of Paris IV-Sorbonne, 191 rue Saint-Jacques, F-75005 Paris, France; e-mail: al.sanguin@orange.fr 
they belong. The physical barrier formed by high mountains has been overcome due to a bold politics of road and rail tunnels. In both cases, cross-border cooperation is supposed to be strengthened by special European Union programs. The six territories in question are inhabited by linguistic minorities (Catalan, Friulian, German, Occitan, Slovene). Their autonomy is more or less strong depending on whether they belong to the quasi-federal Spain, the regionalized Italy or the centralized France. The same physical-political environments generate similar territorial solutions up to a certain point.

\section{The territorial context and its constraints}

From the triple border point Austria-Italy-Slovenia to the contact between the Julian Alps [Alpi Giulie/Julijske Alpe] and the Karst, the Valcanale or Tarvisiano, the Slavia Friulana and the Goriziano are literally sticked on the western side of the Julian Alps (Steinicke 2001). This branch of the Alpine arc reaching altitudes up to 3,000 m is a range with just a few easy passes and with just three natural corridors: the Slizza Valley (Gailitz in German) converging with the Gail Valley in Austria, the Natisone valleys and the Vipacco (Vipava in Slovene) Valley. Actually, the lower Vipacco basin constitutes the limit between Julian Alps and Karst. These three valleys prompted indeed the development of roads and urban centres functioning as crossroads and markets (CATTARUZZA 2007).

Valcanale (val Cjanal in Friulian, Kanalska dolina in Slovene, Kanaltal in German) is a valley of the Eastern Alps extending from Pontebba to Coccau. It is actually composed of the valleys of Fella, a tributary of Tagliamento, and the valley of the Slizza torrent connected by a valley pass. The Valcanale separates the Carnic Alps [Alpi Carniche/Karnische Alpen] in the North from the Julian Alps in the South. The urban centre of the valley is Tarvisio (Trbiž in Slovene, Tarvis in German).

Slavia Friulana (Scalavanie in Friulian, Benecija or Beneska Slovenija in Slovene) is an area of hills and mountains located in the Julian prealps of eastern Friuli and extending from Cividale del Friuli to the Natisone Valley and the mountains near Kobarid (Caporetto in Italian) in Slovenia.

The Goriziano is located around the middle course of the Isonzo (Soča in Slovene), the "most beautiful blue river" of Europe, and includes Gorizia (Gorica in Slovene, Görz in German). This area is characterized by hills with vineyards and karstic soils.

Valcanale, Slavia Friulana and Goriziano are sharing a common feature: In all of them hills or mountains meet a plain. This explains why, since historical times, these mountain communities are a hub of different cultures and languages as well as places of complicated historical connections: Romance people (Friulians and Italians), e.g., co-exist with Slovenes and German-speakers (Bufon 2002). 
In the heart of the Pyrenean cordillera [French Pyrénées, Spanish Pirineos, Catalan Pirineus, Occitan Pirenèus, Aragonese Perinés, Basque Pirinioak], the Val d'Aran, Andorra and Cerdanya are located in an upper mountain milieu which was not really sculptured by quaternary glaciers. Consequently, unlike the Alps, the Pyrenees do not feature traffic corridors, suffer from a "lack of aeration" and have only narrow valleys penetrating hardly to the divide.

The Val d'Aran (Valle de Aran in Spanish, Vall d'Aran in Catalan, Val d'Aran in French) constitutes the upper valley system of the Garonne and is an exception within Spain, because it is the only Spanish territory in the Pyrenees located on the Atlantic slope. Up to 1948, Val d'Aran was not connected with Spain by road.

Andorra comprises the upper valleys of Valira (a sub-system of the Ebro hydrographic basin) with two long and narrow valleys. Up to 1933, the country was not connected with France by road.

Cerdanya [Cerdana in Spanish, Cerdagne in French] is a graben of high altitude $(1,600 \mathrm{~m})$ located between two mountain ranges. Its access from France is not easy.

The three Eastern Pyrenees' territories share a common physiographic feature: The valleys perpendicular to the general axis of the cordillera dispose only of a few easy communications with neighbouring valleys. This explains why these mountain communities were more or less isolated during history and formed a kind of small Pyrenean republics, where the local language was able to survive.

\section{Border communities: A story of wrangling and tossing}

The modern border between Italy and Slovenia coincides more or less with the border between the Republic of Venice and the Habsburg Empire between 1521 and 1797. The section between Predil [Passo del Predil/Predel] and Natisone coincided with this former border also between 1866 and World War I. It makes use of the orography of the Julian Alps and represents one of the most stable boundaries in Europe.

But things were different north and south of this section. During the Napoleonic period, the border between the Kingdom of Italy and the Napoleonic Illyrian Provinces followed the Isonzo Valley from its source to its mouth into the Adriatic. Only after World War I, near the present Italian-Austrian-Slovenian triple point, the valley pass of Rateče became for the first time the international border. Despite its hydrographic aspect, the new border caused much unpleasantnesses for the local population living on both banks of the Isonzo.

If the expression of a wrangled and tossed border is used, this is because it underwent at least three major changes between 1866 and 1947. In 1866, when Austria abandoned the Lombardo-Venetian Kingdom in favour of the newly unified Italy, the 
new Austrian-Italian border was fixed in such a way that the central sector PredilNatisone was awarded to Italy, while Valcanale and the lower Isonzo Valley (from Cormons and Gorizia to Grado) remained with Austria. All the way from Monte Croce Carnico/Plöckenpass to the laguna of Marano, this resulted in disruptions. Thus, the rail link Udine - Tarvisio lost its importance. On the other hand, Gorizia - well located in a wider hinterland and now far from the 1866 boundary - developed its role of a regional center (PROST 1973).

By the Treaty of Rapallo (12 November 1920) signed between Italy and the young Yugoslavian state, the border shifted towards the East along a line running from the present Austrian-Italian-Slovenian triple point to Sušak, an eastern suburb of Fiume [Rijeka]. The new Italian province of Gorizia preserved the town's role of a regional center, because its limits coincided with those of the former Austrian province of Görz.

The Treaty of Paris (10 February 1947) settled the issue of the Italian-Yugoslavian border (Moodie 1945). During the peace negotiations, the principle of ethnic balance, promoted by France, had been accepted: A political boundary must coincide as much as possible with ethnic boundaries, but, if this is not possible, leave in both countries an approximately identical number of members of ethnic minorities. Valcanale and Slavia Friulana were assigned to Italy, while the town of Gorizia was cut by the new boundary. As a result, thousands of Slovenes became Italian citizens without any consent. The same was true for Italians, even more numerous, in Tito's new Yugoslavia.

Gorizia and the Goriziano had hardly been affected by the 1866 and 1920 border changes. But by the 1947 border Gorizia was not only partitioned, but lost also most of its hinterland and became a mutilated town. Tito's Yugoslavia constructed the new town of Nova Gorica by structuring eastern quarters of the ante-partition Gorizia and new Socialist-type quarters. The new 1947 border meant a severe cut for this urban area. On an area of $309 \mathrm{~km}^{2}$ Nova Gorica hosts currently 35,332 inhabitants, while Gorizia (41 $\mathrm{km}^{2}$ ) suffered from the demographic consequences of the partition: while it had still 40,625 inhabitants in 1948, it were only 35,946 in 2009. Under the conditions of the Single Market, the Euro Zone and the Schengen Space, the critical question is how to convert two twin cities with almost the same population amounting to a total of 70,000 into a well-performing bi-national and cross-border Greater Gorizia (CocCO 2002).

In the Pyrenees, border location played another role than in the Julian Alps. The difficult orography led to the fact that many mountain communities lived in isolation and in the shape of small Pyrenean republics which changed their political affiliation according to historical circumstances. The Val d'Aran formed part of the Kingdom of Aragon, then of the County of Bearn, the County of Cominges, the County of Bigorre, the Kingdom of Catalonia and finally the Kingdom of Spain. All these political authorities respected and guaranteed the privileges and autonomy of Val d'Aran until their annulment by the Spanish monarchy in 1833 (SANGUin 1994). 
The border location of Andorra and the competition for controlling it on the cordillera's both sides brought the competitors to an original political solution: condominium by self-government. So the famous Parity Act of 1278 was signed by the Bishop or Urgell and the Count of Foix. The Bishop and the Count became co-princes of Andorra and they grant self-government to the Andorran valleys. Consequently, from that date, Andorra had its own parliament and government. This subtle solution let Andorra escape all turmoils occuring during the following centuries. The principality remained safe of WW I, Spanish Civil War and WW II.

Cerdanya walked along another historical-political route. This altiplano belonged for a long time to the Crown of Catalonia (till the $15^{\text {th }}$ century), then to the Kingdom of Spain. By the clauses of the Treaty of the Pyrenees (1659), Spain transfered the western half of historical Cerdanya to France, except the exclave of Llivia. In fact, from 1659 onward the Cerdan society slowly diverged in everyday life towards two different political and cultural spheres, France and Spain (MANCEBo 1999).

\section{Politics of transport and circulation}

Located along the international rail track Venice [Venezia] - Vienna [Wien] and along the highway A23 Venice - Klagenfurt am Wörthersee, Tarvisio (4,800 inhabitants), the urban centre of the Valcanale, is virtually located at European crossroads. The small town is enjoying a new development of tourism due to skiing without borders between Italy, Austria and Slovenia as a direct consequence of the Single Market, the Euro Zone and the Schengen Space. The fall of the Berlin Wall and the European Unions' (EU's) enlargement to the East generated an increasing tourism from eastern Europe and an interesting urban development of Tarvisio.

Slavia Friulana as a network of three valleys (Natisone, Alberone, Cosizza) converging towards Cividale del Friuli (11,600 inhabitants) would have profitted, if this town had developed in a centre of tourism. But this did not happen, although the town has one of the most precious cultural heritages in Friuli-Venezia Giulia.

Gorizia, having lost the Isonzo and Natisone valleys as its natural hinterland, was duplicated beyond the Italian-Yugoslavian border by Nova Gorica, a new town with similar commercial functions. But even after the new highway $\mathrm{H} 4$ connected Gorizia with Ljubljana, the town, which had become famous by Hemingway's novel The Farewell to Arms, does not receive too much tourism. This is also due to the fact that it never had significant touristic ambitions (Gasparini \& Del Bianco 2003).

In the Valcanale/Tarvisiano, trade and traffic experienced a significant increase. Actually, Tarvisio is acting as a kind of relay between Northern Italy and Austria, the Czech Republic and Slovakia. 
Cividale and its valleys, however, had no increase of this kind. A small road connects the upper Natisone Valley with Kobarid in Slovenia. In the winter season, its continuation, the upper Isonzo [Soča] road, is closed just behind Bovec.

A few years ago the opening of the highway H4 Gorizia - Ljubljana via Postojna made circulation with Slovenia easier. The extension of the Schengen Space across the Italian-Slovenian border on 21 December 2007 considerably changed the transport context in the Goriziano. The autoporto (truck station) nearby Gorizia shares with the Trieste autoporto a considerable amount of traffic. Corridor 5, one of the multimodal European corridors, is under discussion regarding its practical implications. So far there is no definite solution for the project, which is supposed to connect the nodes along the axis Venice - Gorizia - Trieste - Ljubljana - Budapest - Bratislava - Užgorod - L'vìv. It is justified to say that along the Julian Alps one is attending the death of a border and the birth of a hinge (ZaGo 2000, GASPARINI 2001).

With mass tourism appearing during the 1970s on the Iberian Peninsula, flows and circulation through the Pyrenees experienced an exponential increase. Like in other parts of the European Union, the acceleration of this phenomenon is due to the Single Market, the Euro Zone and, above all, the Schengen Space. Consequently, the role of the France-Spain-Andorra international border has considerably changed within three decades turning slowly into a kind of EU's inner border (SANGUIN \& GUIRAUD 1995).

Facing this radical change of transpyrenean relationships, France, Spain and the European Commission implemented politics and programs for erasing the physical barrier represented by the Pyrenean Cordillera. This politics began to take shape with the opening of transpyrenean road tunnels in the three territories. Val d'Aran, Catalonia's dead angle, had for a long time totally been isolated from Spain because of the mountain range. In 1948, a road tunnel was opened and a new high performing tunnel (the Juan Carlos Tunnel) has replaced it in 2007. Located on the ToulouseZaragoza axis, the Val d'Aran tunnel is a key link regarding the territorial recombining at work in the Pyrenees.

In Andorra, the Envalira Tunnel located below the Envalira Pass $(2,407 \mathrm{~m})$, the highest road pass in the Pyrenees, acts as a subsidiary for the Puymorens Tunnel. The Envalira Tunnel allows Andorra to catch tourist flows which would otherwise run through the double tunnel system, namely the Puymorens Tunnel and the Cadi Tunnel, both judiciously located on the European axis Toulouse - Barcelona.

Cerdanya benefits from the positive repercussions of this tunnel axis while Latour de Carol, a Cerdan village, is acting as railway crossroads from Barcelona, Toulouse and Perpignan. 


\section{The economy of small border territories}

Tarvisio, the main centre of Valcanale, is decreasing in population since 1961. Its tourism is concentrated on winter thanks to the Three Borders Ski Resort (Austria, Italy, Slovenia). Tarvisio has the famous ski pist "Di Prampero" at the Monte Santo di Lussari. Frequently, Tarvisio accomodates the events of the Alpine Ski World Cup. Summer tourism enjoys the beautiful lakes of Fusine and Predil as well as the summits of the crestline which were the theatre of terrible trench warfare during World War I (Mangart, Monte Canin/Kanin, Monte Rombon...). Another source of economic activity is the Mercato, a kind of open-air cheaper store which attracts daily buyers coming from all eastern Europe. In the Natisone Valley, Cividale has a stable population since the 1921 Italian census and was most capable to develop an efficient hinterland as well as to make profit of its remarkable architectural and historical heritage (MINGHI 1994).

In less than 30 years, the Val d'Aran (10,000 inhabitants) shifted from a traditional peasant mountain economy to a well-performing service sector economy based mainly on high-category skiing. The famous Baqueira-Beret ski resort, established in the 1980s, is frequented every winter by King Juan Carlos, Queen Sofia, the Royal Court and the Madrid jet-society. Camping is more or less absent in the Val. Summer tourism is supported by an efficient network of 4- and 5-star hotels and by two paradores (stateoperated luxury hotels). This economic context explains why the Val d'Aran enjoys the highest income per capita in Spain (SANGUIN 1994).

The Principality of Andorra (84,000 inhabitants), independent from Spain and France since 1278, became a sovereign State in 1993. Andorra is not a member of EU but de facto part of the Schengen Space. Its economic success is based upon the duty-free regime which is historically consubstantial with the Pyrenean micro-state (absence of customs duties and VAT). This regime came into force at the beginning of the 1960s due to the emergence of mass tourism. Since the 1970s, Andorra turned into the "biggest duty-free shop in Europe". Such a particular economic system justifies in itself the presence of 12 million visitors and daytrippers every year by means of four million vehicles. Consequently, the volume of imported goods is totally unconnected with the resident population. Actually, it corresponds to a market of more than 12 million consumers.

Pas de la Casa (3,000 inhabitants) represents the quintessence of a borderscape. This artificial village located at 2,050 m altitude has been built above the upper limit of the traditional ecumene. Where a ski resort and a duty-free small town are extending since 1960, only some shepherd cabins could be met in 1945! The place is frequented daily by chartered buses coming from Toulouse used by seniors only for duty-free border shopping without any other tourist activity. The duty-free regime generates a second kind of tourist attendance. Skiing and housing-catering are cheaper than in both neighbouring countries (France and Spain). Moreover, skiing is underlawn by an 
efficient network of ski resorts able to combine sunniness, snow cover and a long ski season - three ingredients so much looked for by skiers. All in all, Andorra appears as an oversized economy due to the duty-free regime (SANGUIN 2006).

Cerdanya (27,000 inhabitants) is the only territory in question which is cut into two parts by the international boundary in absence of any physical obstacle. This binational entity has the privilege of including national and regional parks. In the most eastward section of the Pyrenean Cordillera, Cerdanya offers a network of 10 ski resorts either in Spain or in France (MANCEBo 1999). To a large extent, Cerdanya plays the role of a winter playground for Spanish Catalonia and, above all, for Barcelona. For the French customers, Font Romeu, the biggest town in French Cerdanya, develops its function of a health resort (high-altitude treatments or climatisme).

\section{Cross-border cooperation in the heart of mountain ranges}

From 1949 onwards, and especially after 1955 with the signing of the Trieste and Gorizia Memoranda, the launching of local trade area agreements marked the beginning of a long-term process of opening the border. After the Osimo Treaty (1975) which allowed new peaceful relationships between Italy and Yugoslavia, the opening of the border paved the way to cross-border cooperation in the Julian Alps and in the Trieste area. Three years later, the Alps-Adriatic Working Community was implemented with the membership of 11 different political units: Baranya and Vas for Hungary; Upper Austria [Oberösterreich], Burgenland, Styria [Steiermark], Carinthia for Austria; Lombardy [Lombardia], Veneto, Friuli-Venezia Giulia for Italy; Slovenia, Croatia for Yugoslavia. With 190,000 $\mathrm{km}^{2}$ and 26 million people today, Alps-Adriatic is viewed as a hot spot of European integration. Its aim is to bridge the linguistic, political and social differences making a positive move towards understanding, friendship and peace in this neuralgic part of the continent. Certainly, Alps-Adriatic was the first and most fruitful international association between former Western and Eastern Europe. The fall of the Berlin Wall and the independence of Slovenia and Croatia decreased the political relevance of the Alps-Adriatic project which, today, is somewhat differently carried by the Central European Initiative.

However, in these early cross-border cooperation actions, the Euroregion Euradria project has moved a few tentative steps. This macro-euroregion finds its main goals in the internationalization of the euroregional market, focusing on its bridging role on the West-East economic and transport axis. As a macro-euroregion, Euradria focuses mostly on the need for integrated logistic structures, thus favouring the economic sphere compared to the social and cultural ones. Such an approach is still struggling to develop into a concrete planning platform, the application of which is shared among all 
partners. The main aim of the partnership is to promote the mobility of workers in the cross-border region in the interest of matching labour demand and supply. At present, this cross-border region includes the entire territory of Friuli-Venezia Giulia and the statistical regions of Goriška, Obalno-Kraška and Notransko-Kraška in Slovenia. The framework agreement for cooperation was signed in Trieste in December 2007. In March 2008, this partnership was recognized by the European Commission. With approximately 1.5 million inhabitants, Euradria measures $12,681 \mathrm{~km}^{2}(7,856$ in Italy and 4,825 in Slovenia). The Euradria headquarter is located in Trieste (GASPARINI 2001).

Therefore, it might be complementary and useful to put forward smaller-scale euroregional initiatives stimulating not only economic collaboration, but also the daily social and cultural cross-border life. Hence, the EureGo project linking the Italian Gorizia province with the Slovene Goriška Statistical Region appears as an appropriate effort to re-evoke the Upper Adriatic regional unity (GASPARInI \& Del Bianco 2005). On the border area between Italy and Slovenia, EureGo counts up to 72 municipalities, with a population of 355,127 inhabitants living in an area of $3,804 \mathrm{~km}^{2}$. The EureGo territory hosts 26,775 productive units in different sectors. Commerce, construction and manufacturing are the most developed sectors in this euroregion, mainly in Italy. The EureGo project has at the beginning (2005) been supported by Interreg IIIA ItalySlovenia. Now scheduled within the Interreg program 2007-2013, EureGo has turned into an EGTC (European Group of Territorial Cooperation).

In the Pyrenees, cross-border cooperation began in the early 1980s, when Spain was not yet a EU member, implemented by the Council of Europe. Established in 1983, the Working Community of the Pyrenees hosts eight political entities (Basque Country [País Vasco/Euzkadi], Aquitaine, Midi-Pyrénées, Navarra, Aragon, Andorra, LanguedocRoussillon, Catalonia [Catalunya]) including three countries (France, Andorra, Spain). Even if the Council of Europe is not the EU, the Working Community of the Pyrenees is in charge of the program Interreg IV (2007-2013) for all the Pyrenees.

The Euroregion Pyrenees-Mediterranean has been created in 2008 in the shape of an EGTC (European Group of Territorial Cooperation). Five political entities are members of this euroregion: Aragon, Midi-Pyrénées, Catalonia, Languedoc-Roussillon and the Balearic Islands [Illes Balears]. Surprisingly enough, Andorra, a true Pyrenean state, is not member of the Euroregion, while the Balearic Islands, which have nothing to do with the Pyrenees, are a member.

Like in the case of the Julian Alps area, a third scale of cross-border cooperation is to be found by the Eurodistrict of the Catalan Cross-Border Space. Established in 2009 in the shape of an EGTC, this Eurodistrict is actually a regrouping of urban cooperations. Its members are the Department of Pyrénées-Orientales in France and the Comarca de Girona (Catalonia) in Spain. The most interesting result is the crossborder hospital of Cerdanya established in 2010 and located in Puigcerda, the capital of historical Cerdanya. This first EU cross-border hospital was financed by the program 
Interreg IIIA with a $60 \%$ contribution from the EFRD (European Fund for Regional Development). The Puigcerda cross-border hospital is planned for 30,000 local patients and 100,000 in summer, due to the tourist activities in the area.

The EU has from the very beginning initiated and favoured the model of crossborder cooperation as a protoype of European integration. And there is indeed no doubt that putting together parts of different states, relying on their reciprocal trust, taking advantage of their reciprocal knowledge and making them cooperate in many fields starting from the most concrete is the stroke of genius on the concept of Europe. While such geniality must remain rather implicit, economic advantages are obvious affecting those who "dared" making projects and joint actions of reciprocal usefulness.

\section{Linguistic and cultural autonomy of small mountain territories}

It is not surprising that the combination of physical constraints and a turbulent history has generated a solid base for linguistic and cultural originality in the six small territories. Valcanale/Tarvisiano with its tri-border location is an area with a strong mixing of languages: Friulian, German, Slovene, Italian. According to the HitlerMussolini agreement (1939) about 5,600 German-speaking and 100 Slovene-speaking people (optanti) left the Tarvisiano towards the Third Reich. Only 20\% of them came back after World War II; the others remained in Austria. In the 2000s, around 20\% of the Tarvisiano population are German- or Slovene-speaking. The Valcanale/Tarvisiano represents the single case of a linguistic peninsula in Europe, because four linguistic communities peacefully coexist in an Alpine micro-region. Today, the German, Slovene and Friulian minorities living in the ten municipalities are protected by Italian State Law 482/99. Probably, Tarvisio is the single quadrilingual commune in the EU. Its multilingual school has good success and it conducts a policy of dialogue with and protection of local linguistic minorities.

In Slavia Friulana, the Natisone valleys are an important linguistic island since the $10^{\text {th }}$ century, when Aquileia's patriarchs gave them many privileges. The longlasting autonomy has resulted in a specific culture. For the protection of minorities, some Slovene-speaking schools were established. Unfortunately, the Natisone valleys' population is tragically decreasing since the implementation of the Italian-Yugoslavian border in 1947 which actually acted as a kind of a soft Iron Curtain. In 1951, Slavia Friulana's population amounted to 16,195 people within the seven historical communes. The present population is just 5,995 inhabitants. After 1866 and its attachment to Italy, the local elite gradually abandoned the Slovene language. Italianization accelerated 
after 1933, when Fascism prohibited the use of Slovene in churches. After 1947 and in the time of Cold War, even if the Slovene-speaking people of the Natisone valleys were loyal citizens of Italy, they were considered as suspects and accused of Communist propaganda and philo-Yugoslavism. For this reason the situation of the Slovenes in the Udine province is much worse than in the provinces of Gorizia and Trieste, notably in terms of school rights and cultural rights (VALussi 2000).

Gorizia as a town has a majority of Friulian and Italian speakers and a Slovene minority. The Austrian census of 1910 identified 11\% German-speakers at a time when Gorizia was considered the Nice of the Habsburg Empire. Today, the German language has practically disappeared. During the last decades of Habsburg rule, tensions between Slovenes and Italians were recurrent in Gorizia. The Fascist regime implemented an Italianization process after 1922, but many Slovene schools and institutions remained. Understanding the issue of the Slovenes in Friuli-Venezia Giulia means regarding the centuries-old process of Romanization of Slavonic people. Up to the "national awakening" around 1850 social advancement was for them synonymous with a change to Italian language.

The Aranese idiom spoken in Val d'Aran, a true Occitan in Spain, is the legitimate child of the Catalonian autonomy in the frame of the new constitutional Spain (1978). Val d'Aran is in this way an autonomy within the autonomy. By a double legislative tool, the Law on the Special Regime of Val d'Aran (1990) and the new autonomy statute of Catalonia (2006), Occitan has been declared co-official with Catalan in Val d'Aran. Consequently, schools, the media and culture are managed both in Occitan and Catalan. According to the last census in Spain (2001), Spanish is the mother tongue of $39 \%$ of the Aranese, Occitan the mother tongue of $34 \%$ and Catalan the mother tongue of $19 \%$.

Before and after its transformation into a fully sovereign State (1993), Andorra was always a bastion of the Catalan language in the Pyrenees. The local population is Catalan-speaking (native Andorrans) including the majority of Spanish immigrants, because they are Catalans from Catalonia!

The historical Cerdanya is suffering from its former partition, which was the direct consequence of the Treaty of the Pyrenees (1659). From a linguistic and cultural point of view, Cerdanya is an object of dichotomy between Spanish Cerdanya (Puigcerda) and French Cerdanya (Font Romeu). Roughly speaking, the local population is Catalan-speaking in Spanish Cerdanya. This territorial section of Cerdanya is enjoying the benefits of the Catalonian autonomy as regards schools and cultural life. French Cerdanya, in contrast, is a part of a country which is the archetype of the centralized unitarian state. Consequently, even if the place names are Catalan, the local population is essentially French-speaking despite its clear Catalan roots. The school network is French. Only at the entrance of villages bilingual signposts can be observed. 


\section{Conclusion: A game of similarities and differences}

Among the six territories compared, an important contrast prevails between the territories in the Julian Alps and those of the Eastern Pyrenees: Val d'Aran and Andorra are subjected to natural barriers which do not exist in Tarvisiano, Slavia Friulana and Goriziano. Consequently, Val d'Aran and Andorra and, to a lesser extent, Cerdanya had to construct many road tunnels. This was especially vital for Val d'Aran: Without the Juan Carlos Tunnel linking it with Spain, this Occitan micro-region would have remained a pene-exclave, namely a Spanish territory which would be connected with the rest of Spain only through France. Due to its location at a dead angle and grey zone, Slavia Friulana was not able to overcome its relative isolation. In terms of transport and circulation, the Tarvisiano has two European major highways and railways at its disposal, while such key elements are absent in Val d'Aran, Andorra, Cerdanya and Slavia Friulana.

While Andorra with its duty-free regime and oversized economy appears to be an exception, the other territories share a more classical economic profile. Except the Goriziano and Slavia Friulana, the mountain communities have strongly developed skiing tourism and subsidiary activities. For all of them the economic future lies in the uitlisation of the Schengen Space and cross-border cooperation. Frequently, euroregions and similar cross-border projects are much more empty projects or flashing media annoucements than concrete realizations in the field. On this background the crossborder hospital of Puigcerda or Greater Gorizia are certainly exceptions.

A political aberration, namely the redundance and double use generated by the competition between the Council of Europe and the European Union, has to be mentioned here: Alps-Adriatic versus Euradria, Working Community of the Pyrenees versus Euroregion Pyrenees-Mediterranean. Such redundance results in politicaladministrative stacking, which is ineffective and sterile: in the Perpignan-Girona area working community, euroregion and cross-border district; in the Goriziano area AlpsAdriatic, Euradria, EureGo. Here and there, ironically, they are addressed as crossborder lasagna or millefeuille!

The existence of the "Yugoslavian" Iron Curtain (1947-1976), the ItalianYugoslavian border implemented in 1947 and the late accesses of Austria (1995) and Slovenia (2004) to the EU are the main factors explaining the backwardness of the Julian Alps area compared to the Eastern Pyrenees regarding cross-border cooperation. The Catalonian way to autonomy starting in 1978 (in the new constitutional Spain) has secured significant autonomy also to the small Occitan-speaking Val d'Aran; and Catalonia's autonomy status allows Spanish Cerdanya to blossom in its language and culture, which is absolutely not so with French Cerdanya. 


\section{Bibliography}

Bufon M. (2002), Confini, identità ed integrazione. Nuove prospective per l'Alto Adriatico. Trieste, SLORI.

Cattaruzza M. (2007), L'Italia e il confine orientale. Bologna, Il Mulino.

Cocco E. (2002), Metamorfosi dell'Adriatico Orientale. Faenza, Homeless Book.

GASPARInI A. (ed.) (2001), Progetto di sviluppo e conoscenza reciproca Italo-Slovena. San Pietro al Natisone, Comunità Montana Valli del Natisone.

Gasparini A., Del Bianco D. (2003), Modello flessible di sviluppo per l'Isonzo. Gorizia, ISIG.

Gasparini A., Del Bianco D. (2005), EureGo. Progetto di una euroregione transfrontaliera. Gorizia, ISIG.

MANCEBo F. (1999), La Cerdagne et ses frontières, conflits et identités transfrontalières. Perpignan, Editions El Trabucaire.

MingHI J. (1994), The Impact of Slovenian Independence on the Italo-Slovene Borderland: An Assessment of the First Three Years. In: Gallusser W. (ed.), Political Boundaries and Coexistence, pp. 88-94. Bern, Peter Lang Verlag.

Moodie A.E. (1945), The Italo-Yugoslav Boundary: A Study in Political Geography. London, G. Philip.

Prost B. (1973), Le Frioul, région d'affrontements. Gap, Editions Ophrys.

SAnguin A.L. (1994), Le Val d'Aran (Catalunya) ou la réémergence politico-culturelle du fait occitan dans les Pyrénées. In: Géographie et Cultures, 12, pp. 3-14.

SAnguin A.L. (2006), Andorra, the European Micro-State's Archetype. The Borderscape's Original Features of a Duty-Free Exclave, www.unitn.it/events/borderscapes/abstracts.htm

Sanguin A.L., Guiraud, F. (1995), The Pyrenees: Death of a Border, Birth of a Hinge? In: European Spatial Research and Policy, 2, 2, pp. 43-53.

SteInICKe E. (2001), The Val Canale. Ethno-Geographical Problems of a Quadrilingual Italian Border Region. In: Koter M., Heffner K. (eds.), Changing Role of Border Areas and Regional Policies, pp. 222-227. Lodź, University of Lodz Press.

VALussi G. (2000), Il confine nord'orientale d'Italia. Gorizia, ISIG.

ZAGO M. (2000), La cooperazione transfrontaliera nel Friuli Venezia Giulia. Trieste, Regione Autonoma Friuli Venezia Giulia. 
